\title{
Caracterización morfológica de agregados para concreto mediante el análisis de imágenes
}

\section{M orphological characterization of concrete aggregates by means of image analysis}

\author{
María Patricia León*1, Fernando Ramírez** \\ * Pontificia Universidad Javeriana, Bogotá. CO LO M BIA \\ ** U niversidad de Los Andes, Bogotá. CO LO MBIA
}

Fecha de recepción: 22/ 10/2009 Fecha de aceptación: 10/ 04/ 2010

Resumen PAG. 215 - 240

La morfología de los agregados influye en las propiedades del concreto en estado fresco y endurecido, sin embargo no se ha establecido una correlación entre parámetros de forma y características del concreto de manera que la incidencia de la forma sea tenida en cuenta en el diseño de la mezcla. La medición de la forma por los métodos tradicionales es subjetiva, por esta razón últimamente se han utilizado tecnologías de análisis de imágenes para determinar las características de forma de las partículas. En este estudio se determinaron las características morfológicas de diferentes agregados usando los métodos tradicionales y el de análisis de imágenes con los descriptores de Fourier, y se determinaron las propiedades mecánicas de concreto preparado con agregados de diferente forma con el fin de evaluar la influencia de esta en las propiedades del concreto fresco y endurecido. Los resultados indican que las propiedades mecánicas no se ven afectadas de manera importante por la forma de los agregados, sin embargo, influye significativamente en la trabajabilidad.

Palabras Clave: Concreto, morfología de agregados, análisis de imágenes, resistencia a la compresión, trabajabilidad

Abstract

Properties of fresh and hardened concrete are affected by the morphological characteristics of the aggregates. However, there is not an established correlation, between the aggregate shape and the concrete properties, to be taken into account during the mix design process. Conventional aggregate shape measurement methods are subjective, and that is why image analysis has been recently used to determine the morphological characteristics of particles. In this study, the morphological characteristics of coarse aggregates from two different sources are determined using both, conventional methods and image analysis by means of Fourier descriptors. Mechanical properties of concrete prepared with coarse aggregates having different elongation indexes were evaluated. Results indicate that the aggregate shape has little influence in the concrete compressive strength and elastic modulus, while its influence in workability is significant.

Keywords: Concrete, aggregates morphology, image analysis, compressive strength, workability

\section{Introduction}

Stone aggregates are fundamental elements of hydraulic concrete, asphaltic concrete and granular bases. Their characteristics affect not only fresh and hardened concrete properties but also its cost. Aggregates occupy between $70 \%$ and $80 \%$ of concrete volume, that is why it becomes important to know the aggregate properties and their influence on concrete properties, in order to improve not only its use and exploitation but also the concrete mix design process.

1 Autor de correspondencia / Corresponding author:

E-mail: mpleon@javeriana.edu.co 
Aggregate shape, texture and gradation characteristics affect the workability, finishing, bleeding and segregation of fresh concrete; and they also affect the strength, stiffness, retraction and permeability and durability of hardened concrete (Q uiroga, 2003).

Cement is the most expensive component of concrete. Cement paste (cement and water) is the element filling the voids among aggregates, provides workability for fresh concrete and creates adhesion or bonding among aggregates once concrete is hardened. The percentage of voids in an aggregate mix is mainly related with its gradation, shape and texture (De Larrard, 1999). The voids resulting from aggregates mixes with flat and elongated particles are generally higher than those from rounded particles, therefore, there will be a lower demand of cement paste for rounded aggregates, in order to achieve a desired workability and to obtain an adequate bonding among aggregates. The use of low paste dosages (within certain limits) a part from reducing costs, tends to create less difficulties in relation to cracking, heat of hydration and durability. During recent decades, image analysis techniques have been used to assess the shapes and texture of particules. From those techniques and texture indexes have been obtained, which define such properties quantitatively. Design methods for concrete mixes, do not consider in a direct way the aggregate shape and textures, for instance in the case of the design method ACI 211.1 (1991) the shape effect is partially taken into account by involving the sand fineness modulus and aggregates compact unit mass, however, this method does not establish water amount variations due to such factors. This situation together with limitations in some cities as far as aggregate provision is concerned, because of insufficient exploitation sources, high economical cost and exploitation environmental impacts make really necessary accurately know the characteristics of aggregates and their influence on the concrete properties, in order to explicity and rationally consider such information in the concrete mix design process. 
The main purpose of this study is the morphological characterization of aggregates used in hydraulic concrete mixes and the assessment of their influence on fresh and hardened concrete properties. This project comprises a physical and mechanical characterization of crushed aggregates, from different sources, used for concrete production in Bogota; the registration and interpretation of aggregates digital images from each selected source to obtain their shape characteristics, characterization of fresh concrete (settlement); and the mechanical characterization of hardened concrete (modulus of elasticity and compressive strength), to evaluate the influence of the aggregates morphology on the fresh and hardened concrete properties under.

\section{Theoretical framework}

\subsection{Aggregate shape effect on concrete}

Aggregate characteristics have a major effect on fresh and hardened concrete behavior. The main aggregates characteristics affecting the concrete properties are shape and texture; gradation; absorption; mineralogy; compressive strength and elasticity modulus; maximum size; specific gravity; sulfates attack resistance and hardness. Once the influence of each individual property is determined on concrete behavior, it shall be possible to design more cost effective mixes.

In order to achieve an optimal concrete mix some conditions are required, among others that concrete aggregate mixture compactness is the maximum possible, with a proper workability in order to minimize the amount of cement paste required for aggregate bonding. Likewise, concrete components are required to meet durability, workability, and strength specifications. The compactness assessment of a granular mix is a major problem for the handling and knowledge of concrete (Andersen y Johansen, 1991), and it depends on three fundamental parameters: aggregate size and gradation, shape (morphology and texture) and compaction method of the concrete mix. 
The higher volds content the higher amount of cement paste required. It has been found that the requirement of cement paste is reduced from $4 \%$ to $5 \%$ when a cubic aggregate is used instead of elongated and flat aggregates (Hudson, 1998). Similarly, as the shape of particles affect the aggregate mix compactness, it has a high incidence on the demand for cement paste, and therefore on concrete costs, also affecting workability and the mechanical properties of concrete. Aggregate shape and texture affect the compact unit mass, and therefore play an important role for mortar performance and fresh concrete and it may indirectly affect its strength by affecting concrete pouring and compaction.

2.1.1 Aggregates shape effect on fresh concrete properties

Particles shape affect workability and pouring of fresh concrete. The required amount of cement paste in the concrete mix is associated with the specific surface area of the aggregates. The particles having a lower specific surface area, such as cubic or rounded particles, require a lower amount of cement paste in order to achieve the same workability than a concrete mix made with higher specific surface area aggregates, such as those containing elongated and flat particles (Shilstone, 1999). In addition, flat, elongated, angular and rough particles resulting a high voids when arranging themselves, thus demanding more sand into the mix to deliver concrete workability. When this happens, the fineness of the aggregate mix is higher, i.e., it has a higher specific surface area, and therefore, paste demand increases (Legg, 1998). Apart from having a direct effect on the mix workability, flat, elongated, angular and rough particles produce mixes that make the concrete surface finishing and compactness difficult. Although surface texture affects workability, its influence is not that much representative as gradation and aggregate shapes (Galloway, 1994). Water demand into the mix is also influenced by the aggregates shape and texture. $A$ higher demand of water to obtain a given workability reduces strength and increases concrete bleeding. 
2.1.2 Aggregate shape effect on hardened concrete properties

Aggregates shape and texture, apart from affecting significantly fresh concrete workability, have an effect on strength and durability of hardened concrete. Texture affects adhesion between the coarse particles and the mortar matrix thus reflecting a strength variation. Rough particles tend to create higher strengths than smooth particles (Kaplan, 1959), specially flexural strength (Galloway, 1994). However, rough particles increase water demand for a given workability, thus reducing strength and durability.

Durability is associated with a low content of water, so angular, flat and elongated aggregates negatively affect concrete durability since they increase water demand. In the case of concrete pavements, flat particles located near the surface preventing bleeding of mortar water located under the particle, causing damage on the surface and consequently a decrease of pavement duration (Kosmatka, 1994).

Alexander (1996) stated that aggregates shape and texture have a direct effect on strength influencing the strength concentrations on the composite material and the micro cracks and cracks before and after the failure. Mehta and Monteiro (1993) found that, aggregates shape and texture also affect the shape of the concrete stress-strain curve, since aggregates morphology influences the appearance of micro cracks in the transition zone. The influence of aggregates shape on concrete strength is controversial. Although, it has been observed that concretes manufactured with aggregates of different shapes and with a given cement content, can reach similar strengths, some authors ensure that concrete manufactured with rounded and cubic shape aggregates tend to produce higher strengths than those with elongated and flat shapes (Shilstone, 1990).

In accordance with previous statements, there are different specifications limiting the content of elongated or flat particles aggregates used for concrete production. For example concrete specifications in Spain specify that the weight percentage of flat particles must be less than $35 \%$ of the total concrete weight. British regulation states that this percentage must be less than $40 \%$. 
Specifications by the Instituto de Desarrollo U rbano de Bogota indicate that the maximum percentage of elongated and flat particles must be from $15 \%$ to $20 \%$ depending on the kind of traffic.

\subsection{Particles shapes analysis}

Shape, angularity or roundness, and surface texture are three concepts related with the morphological analysis that represent space geometrical variations at different dimension scales (Figure 1). Shape represents space variation at a large dimension scale; angularity or roundness represents variation at a medium dimension scale; and surface texture represent variation at a low dimension scale (Barret, 1980).

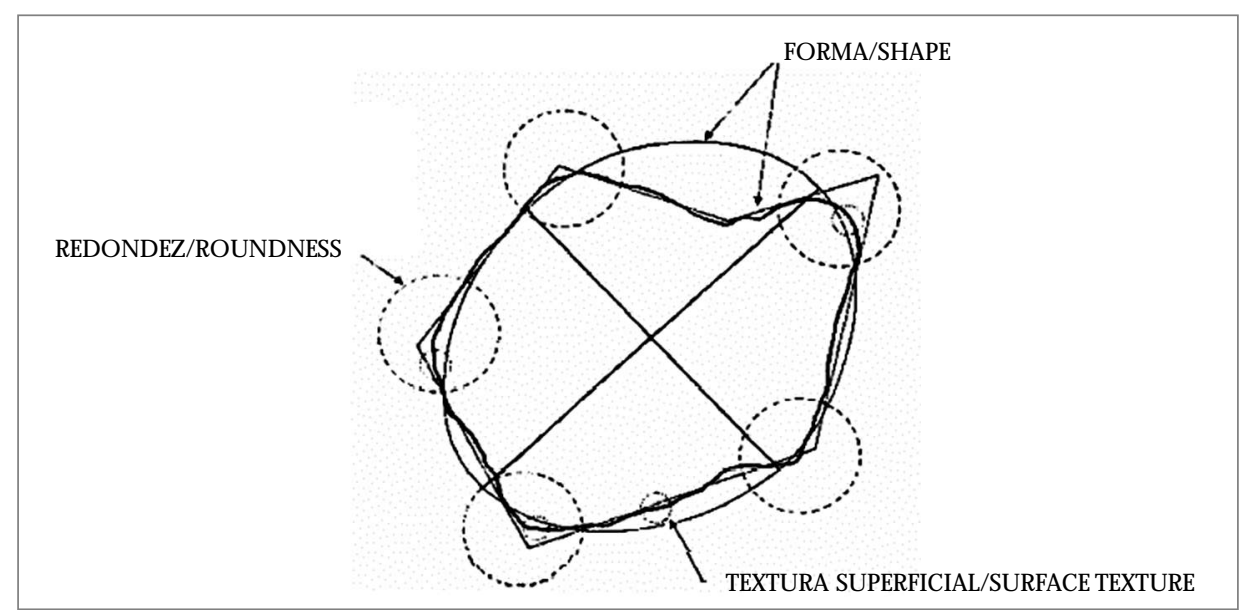

Figura 1. Terminología de forma de la partícula (Barret, 1980) Figure 1. Shape terminology on particles (Barret, 1980)

Shape measurements on concrete aggregates have been widely conducted by means of manual methods employing elongation and flateness gauges. Such measurements are not only time consuming, but also highly subjective. Because of their inefficiency and cost, such measurements tend not to be representative enough to achieve a statistically valid result (Maerz y Zhou, 1999). Then an technologies such as image processing that may increase the accuracy and efficiency of such measurements, which are now being developed to measure aggregates shape, so that they can be implemented for common use. 


\subsubsection{Manual measurement method}

Aggregate flateness and elongation index

The flateness index of an aggregate is calculated as the weight percentage of having its fraction particles, the minimum dimension smaller than a given of the average aggregate dimension. The elongation index of an aggregate is obtained from particles weight percentage having its maximum dimension (length) higher than a given fraction of the average dimensioned. For example the regulation by the Instituto Nacional de Vias de Colombia INV E-230 (1998) defines the flateness index of an aggregate as the percentage of weight of particles, for which minimum dimension (thickness) smaller aggregate than $3 / 5$ of the average dimension; the elongation index of an aggregate is defined as the percentage of weight of particles, for which maximum dimension (length) is higher than $9 / 5$ of the average aggregate dimension.

Fine aggregate voids content in loose condition

This method describes the voids content determination of an aggregate sample in loose condition. By comparing the voids content of different aggregates having the same gradation, and indication of particle are for angularity, roundness and texture can be obtained.

Aggregates shape and texture index

By employing this test method a relative value can be obtained for aggregates shape and texture. This procedure has been used to estimate the effects of such characteristics on the compactness and strength of concrete mixes. The test consists in obtaining the voids content percentage for each material sample with degrees of compaction different, then calculating the aggregate shape index. The index value of a particle is obtained as follows:

$$
\mathrm{I}_{\mathrm{a}}=1.25 \mathrm{~V}_{10}-0.25 \mathrm{~V}_{50}-32.0
$$

Where $I_{a}$ is the index value of a particle, and $\mathrm{V}_{10}$ and $\mathrm{V}_{50}$ are voids content percentages of each sample of compacted material after 10 and 50 strokes per layer, respectively. 
2.2.2 M easurement methods of shape by means of image analysis

Digital image analysis and processing has been employed since 1960s. After the development of computer technologies, the application of digital analysis techniques has been diversified to different areas. In civil engineering, images analysis techniques have been implemented for detection and assessment of tensile stress, establishment of structural conditions, sediments transportation in stream flows, pollutants transportation through porous media, soil deformation, granulometry, and particles shape analysis; and for granular media reconstruction and simulation. Several attempts have been made to characterize particles shape by using image analysis. Some methods have been centered in measuring the shape in general, while others have compared angularity to roundness, and also texture among different shapes (Barret, 1980). Historically, particles shape measurement in soil mechanics has been developed by means of standard charts, useful to compare each particle individually. In the past decade advanced image techniques have been used, such as $\mathrm{x}$-rays scanning and magnetic resonance imaging for the study of structures of granular materials.

Aggregates shape characterization and the influence on the properties of fresh and hardened concrete are the main purpose of this research. Therefore images analysis is conducted by using the Fourier descriptor method, which represents particle shapes properly.

Fourier analysis

Fourier method $(R \theta)$ has been employed to determine some parameters related with the particle shape. In the general theory of Fourier morphological analysis the boundary or contour of a particle (Figure 2) is represented by equation 2 , in terms of Fourier series (Bowman, E. et al., 2000).

$$
R(\theta)=a_{o}+\sum_{m=1}^{\infty}\left(a_{m} \cos n \theta+b_{m} \sin n \theta\right)
$$

Being $\mathrm{a}_{0}$ the average radius of a particle; terms $\left(a_{m} \cos m \theta+b_{m} \operatorname{sen} m \theta\right)$ describe the characteristics of a specific particle boundary, where $a_{m}$ and $b_{m}$ represent magnitudes and $m$ represents frequency; and $\mathrm{R} \theta$ ) is the particle radius for angle. A $\theta$ particle shape is described by means of the following three parameters: 


$$
\begin{gathered}
\text { Forma/Shape }=\sum_{m=1}^{m=n 1} A_{m} \\
\text { Angularidad/Angularity }=\sum_{m=n 1+1}^{m=n 2} A_{m} \\
\text { Textura/Texture }=\sum_{m=n 2+1}^{m=n 3} A_{m}
\end{gathered}
$$

Where $A_{m}^{2}=a_{m}^{2}+b_{m}^{2}$ and $n 1, n 2$, and $n 3$ are limit frequencies that separate shape, angularity and texture, respectively. Wang et al. (2005) reported that for $25 \mathrm{~mm}$ diameter particles, frequency ranking up to $m=4$ define shape; $m$ between 5 and 25 define angularity and $m>25$ define texture.

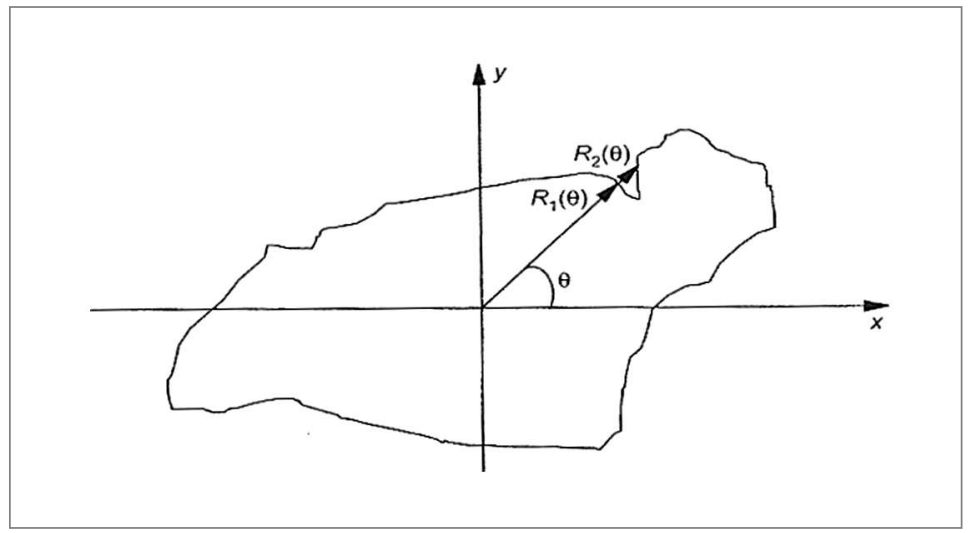

Figura 2. Partícula con dos posibles valores de radio para un mismo ángulo $\theta$ Figure 2. Particle with two possible radius values for a single $\theta$ angle

A restriction exhibited by this method are concavities that may be present on the particle boundary, which provide two possible $R(\theta)$ values for a single angle, as depicted on Figure 2. Clark (1981) found that the Fourier descriptors method could be used to conduct a quantitative analysis of particles shapes. In this method, the boundary of the particle is run at constant speed in the complex plane. The step length is chosen in order to achieve the complete particle boundary path in time $2 \pi$ with $2^{k}$ number of steps. The complex function obtained is shown in Equation 6. 


$$
x_{m}+i y_{m}=\sum_{n=N / 2+1}^{+N / 2}\left(a_{n}+i b_{n}\right)\left[\cos \left(\frac{2 \pi n m}{M}\right)+i \operatorname{sen}\left(\frac{2 \pi n m}{M}\right)\right]
$$

Where $x$ and $y$ are the particle boundary coordinates, $N$ is the total number of descriptors, $\mathrm{M}$ is the total number of points describing the particle, $n$ is the descriptor number, $m$ is the index number of a point in the particle, $a$ and $b$ are the coefficients for each descriptor, and $i$ is the imaginary number. The shape index is calculated as the squared root of square additions of coefficients $a$ and $b$.

The total number of points selected to define the boundary, determines the number of descriptors obtainable from Fourier analysis. The complex nature of equation (6) means that the low order descriptors ( $n=+1$ $a+4$ and $n=-1 a-4$ ) describe the general morphology of a particle and normally have higher coefficients according to described characteristic. Descriptor values normally decrease towards descriptors +64 and -63 (Bowman et al., 2001). For this reason revised bibliography recommends 128 points to conduct the Fourier analysis. It has been found that the first 15 descriptors are usually enough to describe the particle shape at a general level (Sonka et al., 1993). In the case of sands, three terms have been found to be enough to quantify the approximate morphology of the particle.

Descriptors $n=0,-1,-2$ and -3 are related with material shape and provide radius, elongation, triangular and quadrangular characteristics, while descriptor $n=+1$ provides an asymmetry measure; and $n=+2$ and +3 are second descriptors order for elongation and triangularity. Such second order descriptors provide additional information related with roundness at the particle corner edge, but not about the shape of the particle, e.g., a high +3 descriptor would indicate a triangular particle with rounded vertexes (Figure 3). Descriptors 5 to 25 reflect the angular nature of a particle, and those higher than 25 are related with surface texture (Wang, et al., 2005). Typical descriptors of a particle are shown Figure 3. 


\section{Methodology}

\subsection{Materials}

The sources of selected material in this study come from two locations: Guasca and Tunjuelo. In both cases material is crushed, such process affects the morphology of the particles. These sources were selected because they are the most common used by concrete producers in Bogota. Physical characteristics of these materials were determined at the laboratory and they are shown in Table 1. Figures 4 and 5 indicate coarse aggregates gradation and Figure 6 represent fine aggregate gradation. Dotted lines on these figures represent given limits by ASTM C-33 specifications for aggregates used in concrete production.

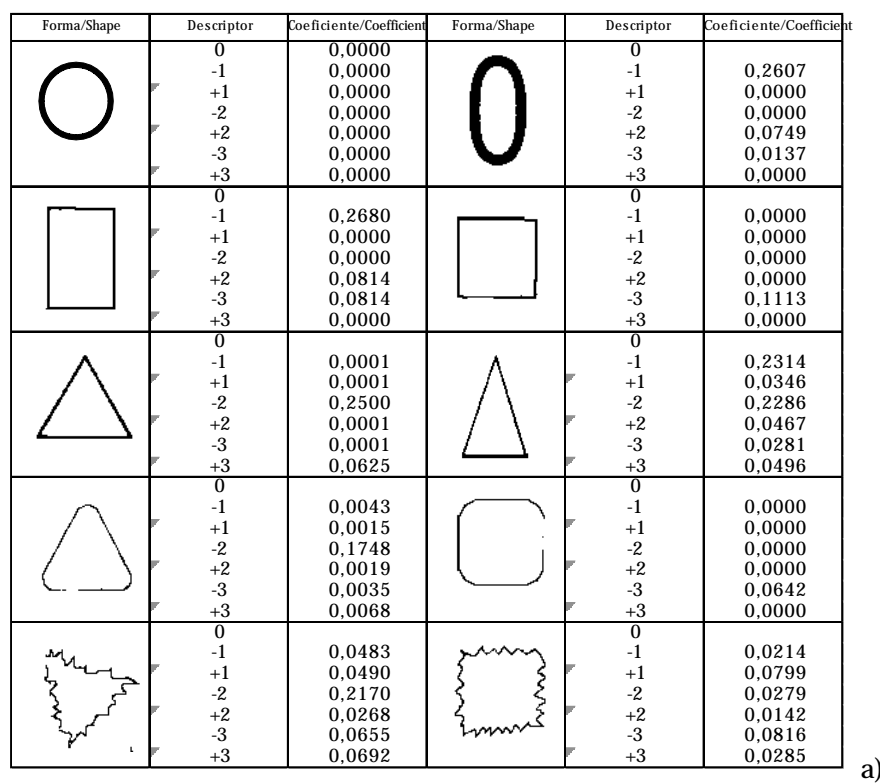

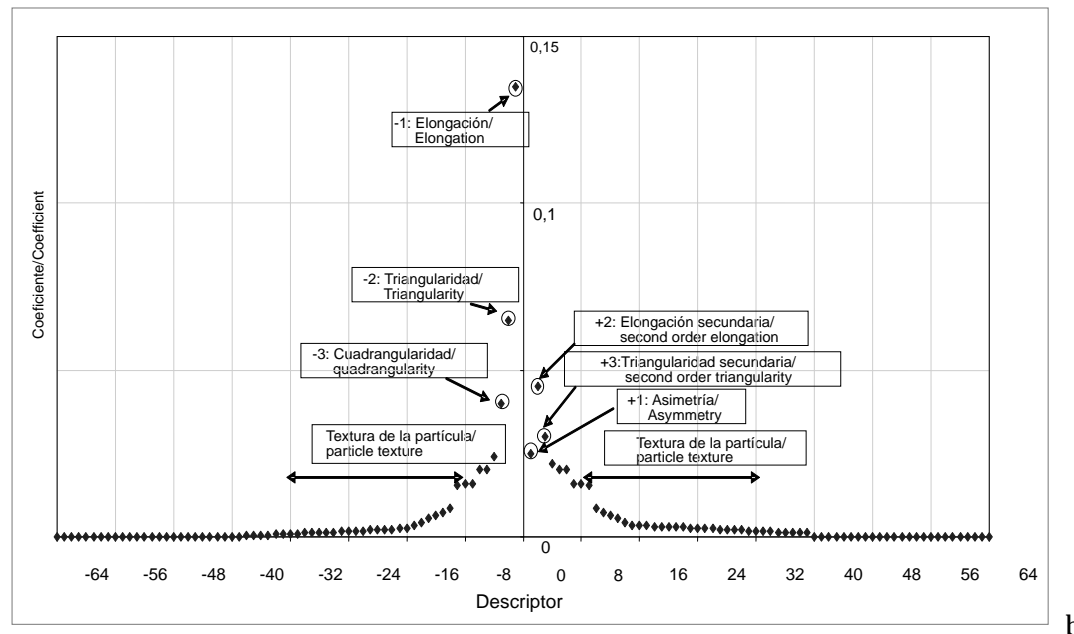

b)

Figura 3. Descriptores de Fourier típicos de una partícula. a. Forma general de particulas de acuerdo a la descripcion morfológica usando descriptores de Fourier. b. Magnitud de los descriptores para una particula típica. (Bowman et al., 2001)

Figure 3. Typical Fourier descriptors of a particle. a) General shape of particles according to morphologic description using Fourier descriptors. b) Magnitude of descriptors for a typical particle (Bowman et al., 2001) 
Tabla 1. Agregados y características físicas

Table 1. Aggregates and their physical characteristics

\begin{tabular}{|c|c|c|c|}
\hline Ensayo/Trial & $\begin{array}{c}\text { Grava } \\
\text { Tunjuelo }\end{array}$ & $\begin{array}{c}\text { Grava } \\
\text { Guasca }\end{array}$ & $\begin{array}{l}\text { Arena } \\
\text { Tunjuelo }\end{array}$ \\
\hline Peso específico aparente $(\mathrm{g} / \mathrm{cm} 3) /$ Bulk density $(\mathrm{g} / \mathrm{cm} 3)$ & 2.620 & 2.372 & 2.564 \\
\hline Absorción (\%)/Absorption (\%) & 2.10 & 3.80 & 1.28 \\
\hline Masa Unitaria Compacta MUC $\left(\mathrm{Kg} / \mathrm{m}^{3}\right) /$ Compact U nit Mass CMU $\left(\mathrm{Kg} / \mathrm{m}^{3}\right)$ & 1515 & 1496 & 1787 \\
\hline Masa Unitaria Suelta MUS $(\mathrm{Kg} / \mathrm{m} 3) /$ Loose U nit Mass $(\mathrm{Kg} / \mathrm{m} 3)$ & 1387 & 1350 & 1575 \\
\hline Módulo de Finura/Fineness M odulus & -- & -- & 3.3 \\
\hline
\end{tabular}

Since the objective of this study is to determine the shape influence on concrete properties, the main problem difficulty is to find materials having different shapes but similar physico-mechanical properties. In order to overcome this inconveniency, coarse aggregate selected only from one source is manipulated and separated using elongation gauges. In this way, two materials with different shape are obtained, having both the same physico-mechanic characteristics: one has $100 \%$ of elongated particles and the other $0 \%$ of elongated particles 1 . Additionally, a third material is considered from non-manipulated aggregate that contains $20 \%$ of elongated particles. This process was conducted on the aggregate coming from the Guasca quarry, since its elongation index is higher than that of the Tunjuelo quarry. Accordingly, Table 2 shows the material classification used for this study.

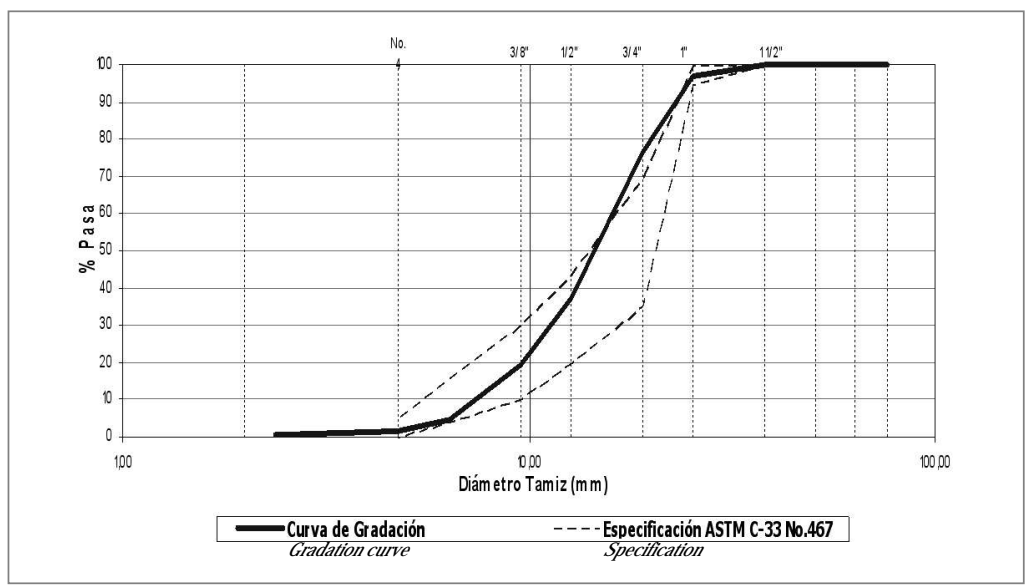

Figura 4. Gradación agregado grueso Guasca

Figure 4. Gradation of coarse aggregate from Guasca quarry

1 De acuerdo a definición dada por el IN VIAS 


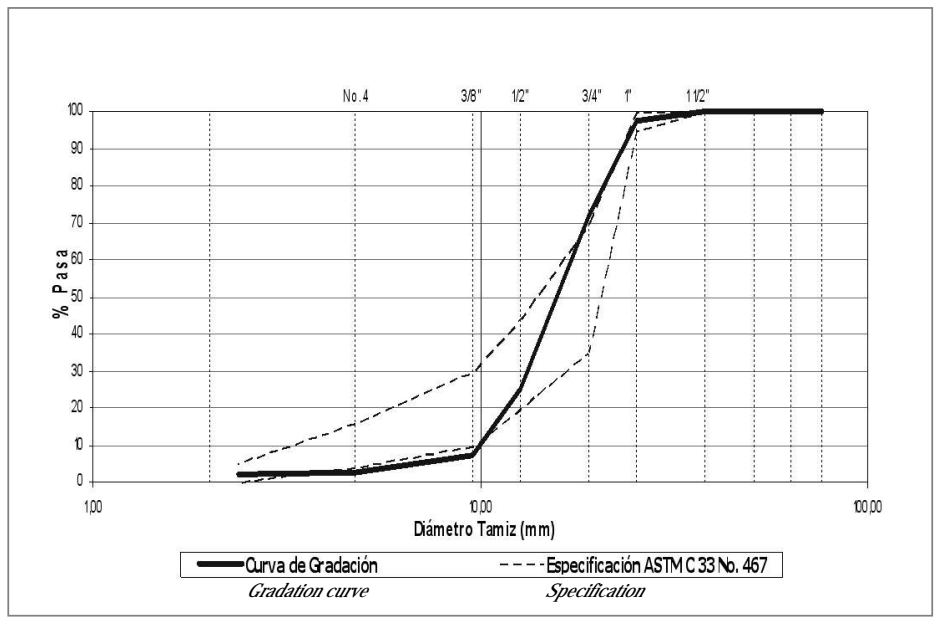

Figura 5. Gradación agregado grueso cantera Tunjuelo Figure 5. Gradation of coarse aggregate from Tunjuelo quarry

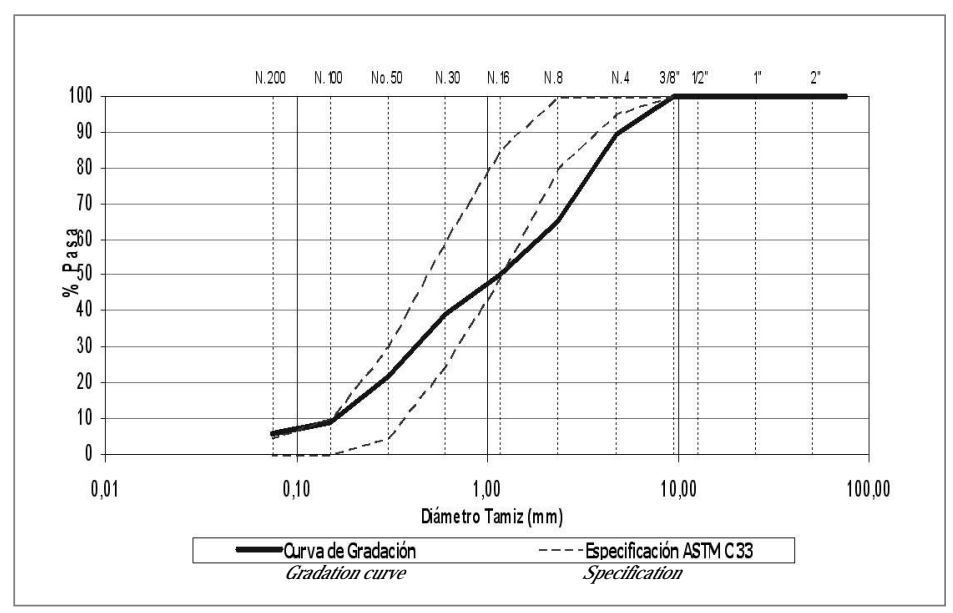

Figura 6. Gradación agregado fino cantera Tunjuelo Figure 6. Gradation of fine aggregate Tunjuelo quarry

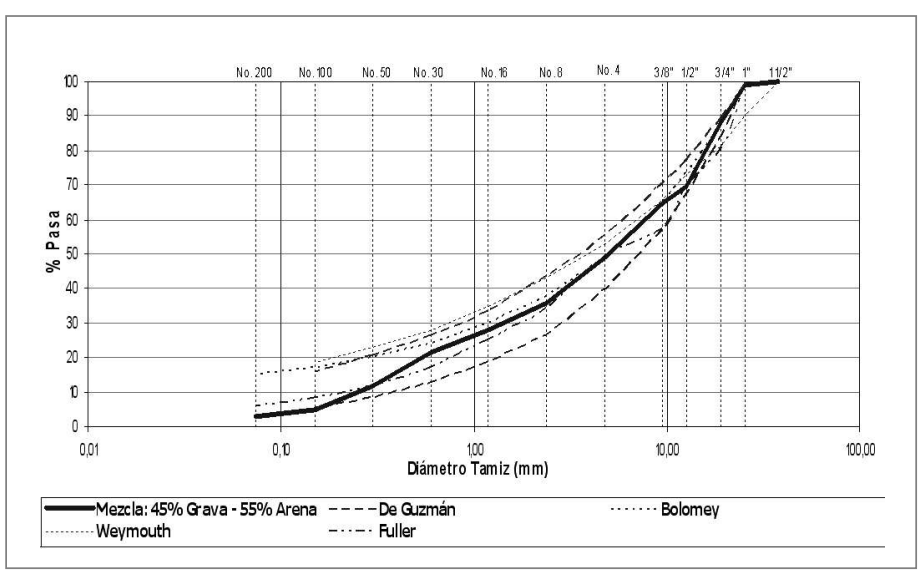

Figura 7. Combinación óptima de agregados Figure 7. O ptimal combination of aggregates

The cement used for the test is Argos-El Cairo, type I, with specific density of bulk density $2.97 \mathrm{~g} / \mathrm{cm}^{3}$ determined at the laboratory using the Le Chaterlier method. 


\subsection{Mix design}

In Bogota most mix designs are based on $\mathrm{ACl}$ 211.1 method. However, it has been found that few aggregates in Bogota meet the specifications of this method. Such method delivers aggregates in accordance with the aggregate maximum size and compact unit mass and with the sand fineness modulus. The selection of the required water amount is determined in accordance with the design settlement, the maximum aggregate size and the content of entrapped air.

The $\mathrm{ACl} 211.1$ method considers the aggregate dossification taking into account the fineness modulus (FM) of the sand, assuming that the aggregates used in the design fit the $\mathrm{ACl}$ specifications limits. Sand from Tunjuelo quarry has a 3.3 FM value, which is higher than the maximum values specified by $\mathrm{ACl} 211.1$, and the granulometry for the sand and gravel used in this study exceeds the $\mathrm{ACl}$ specification. Consequently, aggregates dossification is determined considering ideal gradation curves (Sánchez, 1996), which purpose is to minimize the voids content the mix, without affecting concrete workability. The resulting aggregates combination was $45 \%$ gravel and $55 \%$ sand. Figure 7 shows the optimal aggregate combination together with different limits and ranks of ideal gradations.

Tabla 2. Clasificación del agregado grueso evaluado en el estudio Table 2. Classification of coarse aggregate evaluated in this study

\begin{tabular}{||c|c|c|c||}
\hline \hline Muestra/Sample & Procedencia/Location & Forma/Shape & Índice de Alargamiento ${ }^{1 / \text { Elongated Index }^{1}}$ \\
\hline G1 & Guasca & Natural & $20 \%$ \\
\hline G2 & Guasca & Alargado/Elongated & $100 \%$ \\
\hline G3 & Guasca & No alargado/Non-elongated & $0 \%$ \\
\hline$T$ & Tunjuelo & Natural & $16 \%$ \\
\hline
\end{tabular}

Three concrete mix designs were conducted, mix design type I for conventional concrete using Guasca aggregate with a design compressive strength of $21 \mathrm{MPa}$ and $7.5 \mathrm{~cm}$ of settlement; mix design type II using aggregate from Guasca, for a concrete with a design compressive strength of $21 \mathrm{MPa}$ and $15 \mathrm{~cm}$ of settlement; mix design type III using aggregate from Tunjuelo, for a concrete with a design compressive strength of $21 \mathrm{MPa}$ and $15 \mathrm{~cm}$ of settlement. After the design and adjustment processes on of the concrete mixes, the final material dossifications are shown in Table 3. 
Tabla 3. Diseños de mezclas por $\mathrm{m}^{3}$ de concreto Table 3. Mix design per concrete $\mathrm{m}^{3}$

\begin{tabular}{||l|c|c|c||}
\hline \hline Mezcla/Mix & Tipo/Type I & Tipo/Type II & Tipo/Type III \\
\hline Agregado/Aggregate & Guasca & Guasca & Tunjuelo \\
\hline $\mathrm{f}^{\prime} \mathrm{c}(\mathrm{M} \mathrm{Pa})$ & 21 & 21 & 21 \\
\hline Asentamiento (cm)/Settlement (cm) & 7,5 & 15 & 15 \\
\hline Cemento (Kg)/Cement (Kg) & 356 & 372 & 372 \\
\hline Agua (Kg)/Water (Kg) & 188 & 197 & 197 \\
\hline Agregado grueso (Kg)/Coarse aggregate $(\mathrm{Kg})$ & 765 & 754 & 790 \\
\hline Agregado fino (Kg)/Fine aggregate(Kg) & 948 & 922 & 965 \\
\hline Relación A/C/Relation W/C & 0.53 & 0.53 & 0.53 \\
\hline
\end{tabular}

3.3 Morphological characterization of the aggregates

Aggregates morphological characterization was performed using the manual measurement method for elongation, flateness, and fracture faces indexes, and by means of images analysis.

The manual process of measurement of indexes consists of separating the coarse aggregates by using a series of sieves, and then selecting particles using elong and flat gauges. Such indexes are calculated as the weighted sum of the weights of for each size of elongated or flat particles fraction. The fractured faces is subjective, and it consists of quantifying the porcentage of particles that have approximately $75 \%$ of fractured faces each fraction. The percentage of fractured faces is calculated as the weighted sum of the results for each fraction.

The morphological analysis of the particles by means of images was conducted by using the Fourier descriptors method, described in section 2 , which consists of running the particle boundary in the complex plane at constant speed. In the study, 123 descriptors ( $k=7)$ that, in accordance with the literature report, is enough to properly rebuild the input image.

Images were obtained from photographs taken from groups of 20 particles with a 10- megapixeldigital camera. Then, with the help of an interpretation and images analysis software developed for this project, the geometry of a particles sample was studied for each fraction of the coarse aggregate for each of the materials described in Table 2. A total of 200 particles per fraction, randomly selected, were analyzed. 
The process followed using the developed software can be summarized in two stages. The first stage is the images conversion into a binary format and the determination of particles perimeter coordinates. The second stage consists of processing these coordinates to determine the Fourier descriptors following the method described in section 2.2.2. In this way, quantitative information of the aggregates geometry was available for further correlation with fresh and hardened concrete properties.

\subsection{Evaluation of concrete properties}

Aggregate particles shape may affect the properties of fresh and hardened concrete. Dosing concretes with different aggregates, may affect its workability and also its mechanical properties. Aggregates having different shapes have different specific surface area that is why the amount of paste to achieve the same workability and strength may vary. The properties evaluated in this study to determine the shape influence on concrete behavior are: workability, by means of the settlement test (NTC 396- ASTM C 143), compressive strength (NTC 673-ASTM C 39), and elasticity modulus (NTC 4025- ASTM C 469).

\section{Results and discussion}

\subsection{M orphologic characterization}

The results of the morphologic characterization using manual methods are shown in Table 4.

Tabla 4. Caracterización morfológica Table 4. Morphologic Characterization

\begin{tabular}{|l|c|c||}
\hline Ensayo/Test & Tunjuelo (T) & Guasca (G) \\
\hline Índice de aplanamiento/Flat index (\%) & 4 & 29 \\
\hline Índice de alargamiento/Elongated index (\%) & 16 & 20 \\
\hline Caras fracturadas/Cracked sides (\%) & 60 & 79 \\
\hline
\end{tabular}


It is clear that, although elongation indexes are similar for both sources, that of Guasca is slightly higher. A similar situation occurs in the case of fractured faces, where both aggregates have a high percentage of this property as expected, since both are crushed aggregates.

Shape characterization by means of image analysis using the Fourier method, was conducted for descriptors -1 : elongation, -2 : triangularity, and -3 : quadrature. For this purpose ranges of values were identified for each shape descriptor for which an important variation of shape. For descriptor -1 (Elongation), it is found that when this descriptor has a value lower than 0.05 the elongation is low; for values between 0.05 and 0.17 elongation is high, and for values greater than 0.17 elongation is intermediate. In the same way, descriptor -2 is analyzed, and shows low triangularity for values lower than 0.05 , intermediate for values between 0.05 and 0.2 , and high for values greater than 2 . For quadrature, rounded particles are observed when descriptor -3 is lower than 0.02 , and quadrangular particles for greater values. Such value ranges along with the corresponding shape variations are depicted in Figures 8, 9 and 10 for elongation (descriptor -1 ), triangularity (descriptor -2 ) and quadrature (descriptor -3 ), respectively. In the same way, Tables 5, 6 and 7 present the percentage of particles whith in each elongation, triangularity and quadrature ranges for each type of aggregate.

Assuming that the high elongation range corresponds to the elongation index criteria of the manual method (Table 2), i.e., particles which length to the average size of the fraction ratio is greater than $9 / 5$, then obtained results for both methods are comparable. Considering the errors associated to manual measurement and the sensitivity associated to the selection of ranges in the Fourier descriptors method, such results validate the application of the Fourier descriptor method for the elongation index.

In the case of descriptors -2 and -3 (triangularity and quadrature), there is no significant variation for the three types of aggregates coming from Guasca quarry, as it was expected, since such material manipulation for obtaining G1, G2 and G3 samples only was developed in terms of elongation. 
Furthermore, quadrature and triangularity differences between aggregates from Guasca and Tunjuelo are minimal, because both are crushed materials.

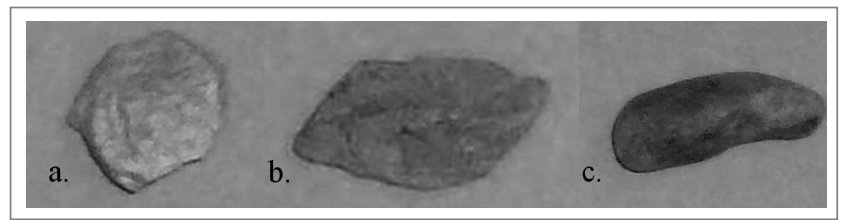

Figura 8. Geometría típica para los rangos del descriptor -1, elongación: a. Elongación baja con descriptor menor a 0.05, b. Elongación media con descriptor entre 0.05 y 0.17 , y c. Elongación alta con descriptor mayor a 0.17

Figure 8. Typical Geometry for elongation ranges of descriptor -1: a. Low elongation with descriptor lower than $0.05 ; \mathrm{b}$. Intermediate elongation with descriptor between 0.05 and 0.17 ; and c. High elongation with descriptor greater than 0.17

Tabla 5. Descripción de elongación (Descriptor -1)

Table 5. Elongation Description (Descriptor -1)

\begin{tabular}{||l|c|c|c|c||}
\hline \hline \multirow{2}{*}{ Rango de Elongación/Elongation range } & \multicolumn{4}{|c||}{ Agregado/Aggregate } \\
\hline & $\mathrm{G} 1$ & $\mathrm{G} 2$ & $\mathrm{G} 3$ & $\mathrm{~T}$ \\
\hline Baja/Low & $9 \%$ & $1 \%$ & $12 \%$ & $10 \%$ \\
\hline Media/Intermediate & $58 \%$ & $24 \%$ & $66 \%$ & $66 \%$ \\
\hline Alta/High & $33 \%$ & $75 \%$ & $22 \%$ & $24 \%$ \\
\hline
\end{tabular}

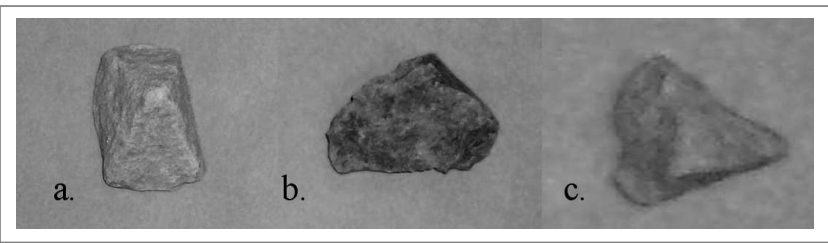

Figura 9. Geometría típica para los rangos del descriptor -2, triangularidad: a. Triangularidad baja con descriptor menor a 0.05 ,

b. Triangularidad media con descriptor entre 0.05 y 0.2 , y c. Triangularidad alta con descriptor mayor a 0.2

Figure 9. Typical Geometry for triangularity ranges of descriptor -2: a. Low triangularity with descriptor lower than $0.05 ; \mathrm{b}$. Intermediate triangularity with descriptor between 0.05 and 0.2 ; and c. High triangularity with descriptor greater than

Tabla 6. Descripción de triangularidad (Descriptor -2)

Table 6. Description of Triangularity (Descriptor -2)

\begin{tabular}{||l|c|c|c|c||}
\hline Rango de Triangularidad/Triangularity range & \multicolumn{4}{|c||}{ Agregado/Aggregate } \\
\hline & G1 & G2 & G3 & T \\
\hline Baja/Low & $47 \%$ & $48 \%$ & $44 \%$ & $53 \%$ \\
\hline Media/Intermediate & $42 \%$ & $42 \%$ & $44 \%$ & $39 \%$ \\
\hline Alta/High & $11 \%$ & $10 \%$ & $12 \%$ & $8 \%$ \\
\hline
\end{tabular}

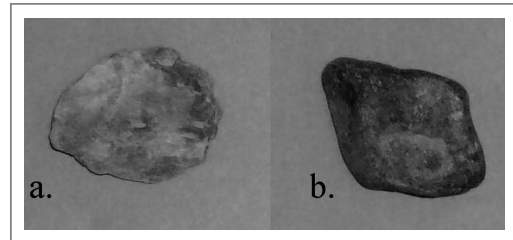

Figura 10. Geometría típica para los rangos del descriptor -3, cuadratura: a. Cuadratura baja con descriptor menor a 0.02 , b. Cuadratura alta con descriptor mayor a 0.02

Figure 10. Typical Geometry for quadrature ranges of descriptor -3: a. Low quadrature with descriptor lower than 0.02; b. High quadrature with descriptor greater than 0.02 
Tabla 7. Descripción de cuadratura (Descriptor -3)

Table 7. Description of quadrature (D escriptor -3)

\begin{tabular}{||l|c|c|c|c||}
\hline \hline Rango de Cuadratura/Q uadrature ranges & \multicolumn{4}{|c|}{ Agregado/Aggregate } \\
\hline & $\mathrm{G} 1$ & $\mathrm{G} 2$ & $\mathrm{G} 3$ & $\mathrm{~T}$ \\
\hline Baja/Low & $33 \%$ & $33 \%$ & $35 \%$ & $40 \%$ \\
\hline Alta/High & $67 \%$ & $67 \%$ & $65 \%$ & $60 \%$ \\
\hline
\end{tabular}

\subsection{Evaluation of concrete properties}

In order to study the shape effect on the properties of fresh and hardened concrete, three mix designs were prepared, which dossifications are presented in Table 3 for the natural aggregates. Mix type I is used to determine the shape influence when the same material dossification is employed. With this purpose and using the dossification corresponding to mix type I, 9 cylinders were prepared for each kind of aggregate G1, G2 and G3. Mix type II is employed to evaluate the effect of morphology keeping the same settlement and water/cement ratio, 9 cylinders were prepared for each kind of aggregate $G 1, G 2$ and $G 3$. It is important to note that mixes type II result in different dossifications for each kind of aggregate $G 1, G 2$ and $G 3$. Finally, mix type III is used to compare natural material coming from two locations ( $\mathrm{G} 1$ and Tunjuelo). Concrete cylinders were tested to evaluate compressive strength and elasticity modulus, and the corresponding results are presented below.

\subsubsection{Shape effect - Same dossification - Mix type I}

The purpose of studying this mix type is to evaluate the effect of different kinds of coarse aggregates (G1, G2 and G3) on concrete workability and strength, when the same material dossification is used in accordance with mix design type I shown in Table 3.

The average results of settlement for each kind of aggregate are shown in Table 8. It is noticeable that there is a great influence of the aggregate shape on fresh concrete workability. For this mix type, the use of material with an elongation index of $100 \%$ (G2) yields a $43 \%$ settlement reduction compared to the obtained settlement from natural aggregate ( $\mathrm{G} 1$ ), while the employment of an aggregate with a $0 \%$ elongation index (G3) yields a settlement increase of $32 \%$. 
Tabla 8. Trabajabilidad de las mezclas tipo I Table 8. W orkability of mixes type I

\begin{tabular}{||c|c|c|c||}
\hline & \multicolumn{3}{|c||}{ Agregado/Aggregate } \\
\hline & $\mathrm{G} 1$ & $\mathrm{G} 2$ & $\mathrm{G} 3$ \\
\hline Asentamiento/Settlement $(\mathrm{cm})$ & $8.2 \pm 1.2$ & $4.7 \pm 0.5$ & $10.8 \pm 0.4$ \\
\hline \hline
\end{tabular}

The results for compressive strength and elasticity modulus show an important variability for each kind of aggregate, partly due to concrete's physical constitution. However, such values did not exhibit significant variations due to change of material shape, as described in Figures 16 and 17 and in Table 9.

Tabla 9. Resistencias a la compresión y módulo de elasticidad mezclas Tipo I Table 9. Compressive strength and elasticity modulus, mixes Type I

\begin{tabular}{||l|c|c|c||}
\hline & \multicolumn{3}{|c||}{ Agregado/Aggregate } \\
\hline & $\mathrm{G} 1$ & $\mathrm{G} 2$ & $\mathrm{G} 3$ \\
\hline Resistencia (M Pa)/Strength (MPa) & $21.7 \pm 2.9$ & $21.1 \pm 3.3$ & $20.7 \pm 3.3$ \\
\hline Módulo de elasticidad (M Pa)/Elasticity modulus (MPa) & $15.1 \pm 2.2$ & $14.5 \pm 1.8$ & $14.4 \pm 1.4$ \\
\hline
\end{tabular}

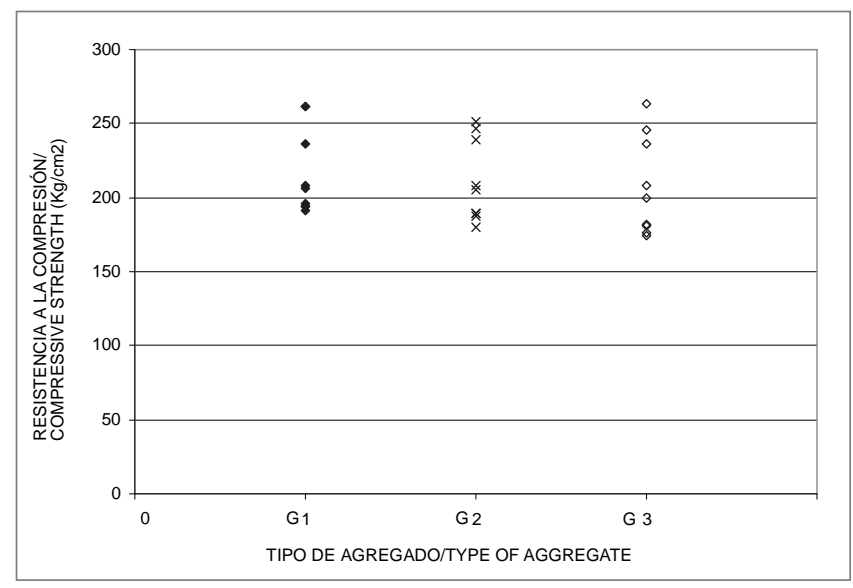

Figura 16. Resistencia a la compresión mezclas tipo Figure 16. Compressive strength - mixes Type I

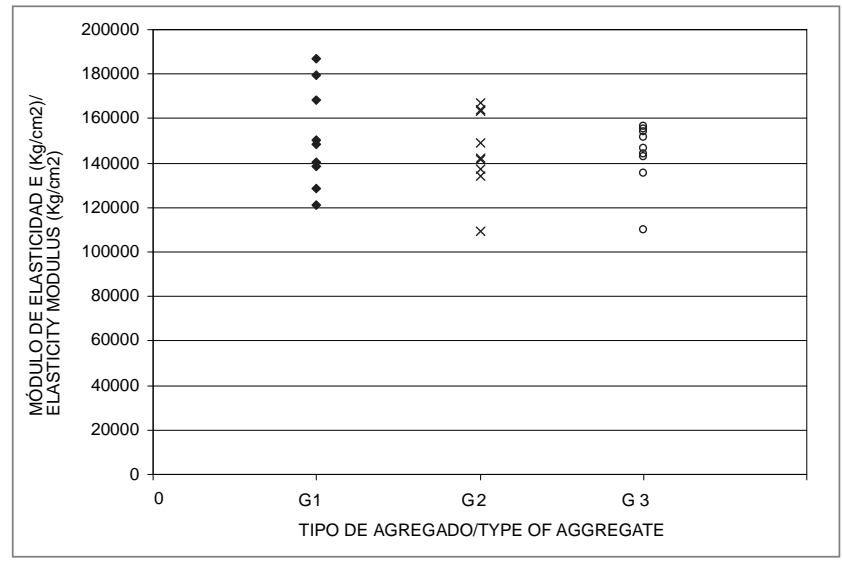

Figura 17. Módulo de elasticidad mezclas tipo I

Figure 17. Elasticity modulus - mixes Type I 
4.2.2 Shape effect - Same settlement and water-cement ratio, Mix type II

Such mixes intend to find the amount variation of cement paste for concrete mixes for different kinds of coarse aggregate $G 1, G 2$ and $G 3$, for a specific settlement $(15 \mathrm{~cm})$ keeping the ratio water/cement ratio constant. In order to achieve the same settlement for different aggregates, the mix design type II (Table 3 ) is taken as a standard, and the coarse aggregate volume is modified until achieving the desired settlement. Such process yields dosages with different cement paste volumes. Final dosages per weight are indicated in Table 10 and the average values of settlement for each kind of aggregate are shown in Table 11.

Tabla 10. Variación en la dosificación de la mezcla tipo II por $\mathrm{m}^{3}$ de concreto debidas a la forma Table 10. Dossification variation of mix type $1 / \mathrm{m}^{3}$ per of concrete, due to particle shapes

\begin{tabular}{|l|c|c|c|}
\hline \hline Agregado/Aggregate & $\mathrm{G} 1$ & $\mathrm{G} 2$ & $\mathrm{G} 3$ \\
\hline $\mathrm{f}^{\prime} \mathrm{C}(\mathrm{M} \mathrm{Pa})$ & 21 & 21 & 21 \\
\hline Asentamiento/Settlement (cm) & 15 & 15 & 15 \\
\hline Cemento/Cement $(\mathrm{Kg})$ & 372 & 379 & 357 \\
\hline Agua/Water (Kg) & 197 & 201 & 189 \\
\hline Agregado grueso/Coarse aggregate (Kg) & 754 & 747 & 769 \\
\hline Agregado fino/Fine aggregate (Kg) & 922 & 913 & 939 \\
\hline Relación/Ratio A/C & 0.53 & 0.53 & 0.53 \\
\hline
\end{tabular}

Tabla 11. Trabajabilidad de las mezclas tipo II Table 11. Workability of mixes type II

\begin{tabular}{||l|c|c|c||}
\hline & \multicolumn{3}{|c|}{ Agregado/Aggregate } \\
\hline & G1 & G2 & G3 \\
\hline Asentamiento/Settlement (cm) & $15.8 \pm 0.8$ & $17.2 \pm 0.3$ & $15.3 \pm 0.4$ \\
\hline
\end{tabular}

The presence of elongated particles involves a higher voids content, and therefore a higher amount of cement paste. Accordingly with results in Table 10, the mix prepared with aggregate type $\mathrm{G} 2$, which has an elongation index of $100 \%$, requires a $1.9 \%$ paste volume increase than the natural aggregate; while the mix of $\mathrm{G} 3$ aggregate, with a $0 \%$ elongation index, requires $4.0 \%$ less cement paste compared to the non-manipulated aggregate mix. Demand of paste increases in $5.9 \%$ for a mix with aggregates without elongated particles (G2), compared to one with $100 \%$ elongated particles (G3). 
Results for compressive strength and elasticity modulus are shown in Figures 18 and 19, and Table 12. There is no significant change in strength for concrete prepared with $\mathrm{G} 1$ and $\mathrm{G} 2$ aggregates. In the same way, the compressive strength and elasticity modulus behavior for $\mathrm{G} 1$ and $\mathrm{G} 3$ aggregates is similar with a minor decrease of compressive strength and elasticity modulus for $\mathrm{G} 3$ aggregate. Accordingly with Table 10 , the mix prepared with $\mathrm{G} 2$ aggregate contains about $2.0 \%$ more paste than the mix prepared with $\mathrm{G} 1$ aggregate; while $\mathrm{G} 3$ mix requires $4.0 \%$ less paste, which indicates that compressive strength and elasticity modulus behaviors can be mainly affected by the paste volume, not disregarding the influence in strenght of the particles.

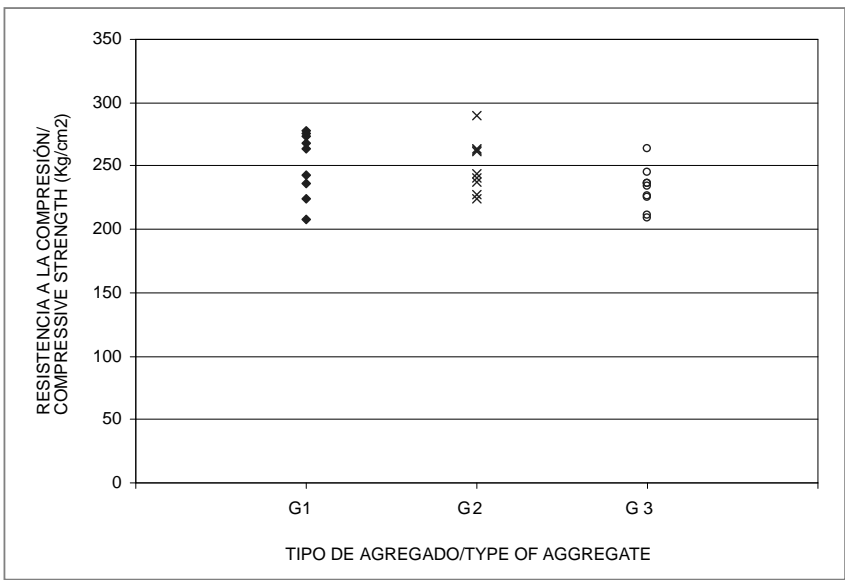

Figura 18. Resistencia a la compresión mezclas tipo II

Figure 18. Compressive strength - mixes Type II

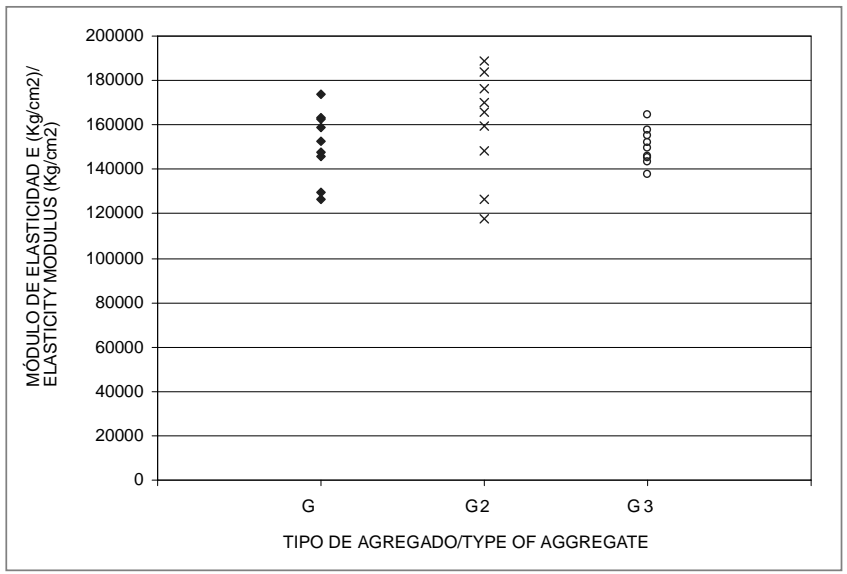

Figura 19. Módulo de elasticidad mez-clas tipo II Figure 19. Elasticity modulus - mixes Type II 
Tabla 12. Resistencias a la compresión y módulo de elasticidad mezclas Tipo II Table 12. Compressive strength and elasticity modulus mixes Type II

\begin{tabular}{||l|c|c|c||}
\hline & \multicolumn{3}{|c||}{ Agregado/Aggregate } \\
\hline & $\mathrm{G} 1$ & $\mathrm{G} 2$ & $\mathrm{G} 3$ \\
\hline Resistencia/Strength (M Pa) & $25.2 \pm 2.5$ & $25.0 \pm 2.1$ & $23.2 \pm 1.7$ \\
M ódulo de elastcidad/Elasticity modulus (M Pa) & $15.1 \pm 1.6$ & $15.9 \pm 2.4$ & $15.0 \pm 0.8$ \\
\hline
\end{tabular}

\subsubsection{Aggregates Influences}

This type of mix intends to compare concrete properties by using aggregates from different locations ( $G$ and T).

Mix designs in this comparison are type I and type III described in Table 3, corresponding to the two previously mentioned aggregates. Settlement results shown in Table 13 are consistent to literature reports, since the elongation index for Tunjuelo aggregate $(T)$ is minor than that of Guasca aggregate (G1).

Tabla 13. Trabajabilidad de las mezclas tipo I y tipo III

Table 13. Workability of mixes type I and type III

\begin{tabular}{||c|c|c||}
\hline & \multicolumn{2}{|c||}{ Agregado/Aggregate } \\
\hline & $\mathrm{G} 1$ & $\mathrm{~T}$ \\
\hline Asentamiento/Settlement $(\mathrm{cm})$ & $15.8 \pm 0.5$ & $18.7 \pm 0.7$ \\
\hline
\end{tabular}

Figure 20, Figure 21, and Table 14 show the results for compressive strength and elasticity modulus in mixes type I and type III. It can be seen that compressive strength and elasticity modulus for $\mathrm{T}$ aggregate are greater than for $G$ aggregate, because $T$ has better physicomechanical characteristics as proven by its higher specific weight and minor resistance to degradation percentage (Table 1).

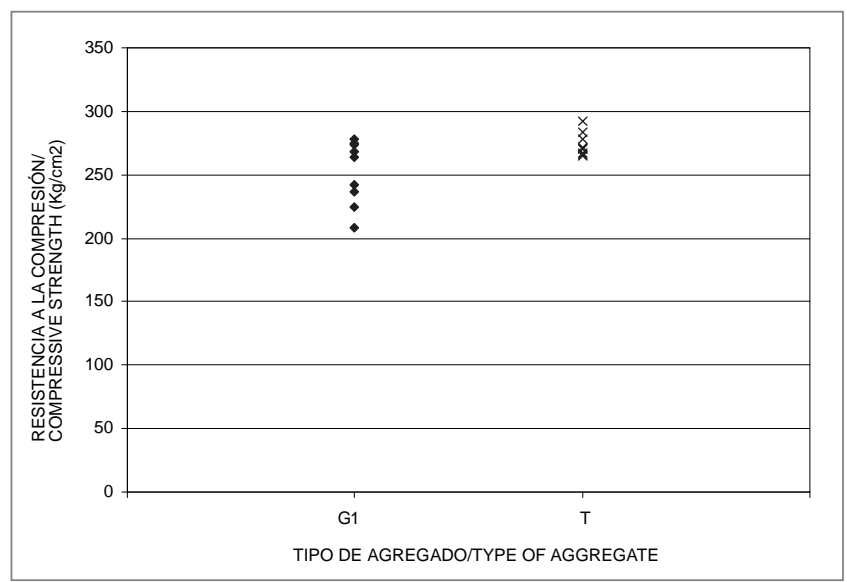

Figura 20. Resistencia a la compresión mezclas tipo 3 Figure 20. Compressive strength - mixes Type III 


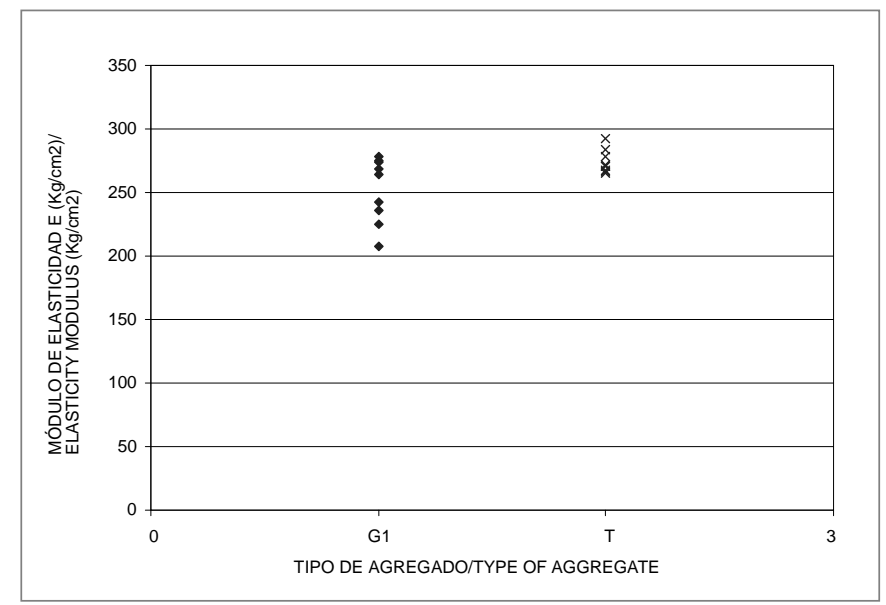

Figura 21. Módulo de elasticidad mezclas tipo 3 Figure 21 . Elasticity modulus - mixes Type III

Tabla 14. Resistencias a la compresión y módulo de elasticidad mezclas Tipo I y Tipo III Table 14. Compressive strength and elasticity modulus mixes Type I and Type III

\begin{tabular}{||l|c|c||}
\hline & \multicolumn{2}{|c||}{ Agregado/Aggregate } \\
\hline & $\mathrm{G} 1$ & $\mathrm{~T}$ \\
\hline Resistencia/Strength (M Pa) & $25.2 \pm 2.5$ & $27.4 \pm 0.9$ \\
Módulo de elastcidad/Elasticity modulus (M Pa) & $15.1 \pm 1.6$ & $18.2 \pm 1.7$ \\
\hline
\end{tabular}

\section{Conclusions}

Aggregates morphology affects the properties of fresh and hardened concrete, with a higher influence on workability than on mechanical properties. Shape measurements by means of traditional methods is subjective, therefore during recent years image analysis technologies have been employed in order to determine the particles shape characteristics. In this study the morphologic characteristics of different kinds of aggregates were determined using traditional methods, and image analysis by means of Fourier descriptors, in order to evaluate the influence of the elongation of the particles on the concrete properties: settlement, compressive strength and elasticity modulus. Based on this research, materials, number of samples and analyses considered, the following conclusions can be obtained:

a. The values obtained for elongation from manual methods and Fourier description analysis, yield minor differences. Such differences are originated by errors associated with manual measurements and the sensitivity in the selection of ranges in the Fourier method. 
b. Mixes prepared with the same mix dossification show significant settlement variations for different kinds of aggregates. Elongated particles decrease concrete settlement and, therefore, reduce its workability. This implies that adjustments must be made on the concrete mix design in order to obtain a desired workability.

c. Compressive strength and elasticity modulus of mixes prepared with the same dossification, but different content of elongated particles, do not show significant differences, therefore, shape is not an important factor on concrete mechanical properties.

d. For mix designs using different shapes aggregates for a given settlement, it was found that the paste volume vary from $5.9 \%$ between aggregates with low elongation index (G2) and high elongation index (G3). Such mixes showed similar behaviors for compressive strength and elasticity modulus.

e. By comparing the results of compressive strength and elasticity modulus on concretes prepared with aggregate $T$ and $G 1$, it is noticeable that $T$ has higher strengths than aggregate $G 1$, because $T$ has better physicomechanical characteristics as proven by its higher specific weight and minor resistance to degradation percentage.

\section{Referencias / References}

Alexander M. (1996), "Aggregates and the deformation properties of concrete". ACl Materials journal, Vol. 6, 93 p. 576. Andersen P.J y Johansen V. (1991), "Packing Handbook, a Guide to Determine the O ptimal Gradation of Concrete Aggregates" Report to Strategic Highway Research Program, SHRP C-206, USA, GMIC N o. 901001

ASTM (2003), “ASTM C-33. Standard Specification for Concrete Aggregates”, American Soci-ety for Testing and M aterials, Philadelphia, USA.

Barret P.J. (1980), "The shape of rock particle, a critical review". Sedimentology. Vol. 27, pp. $291-303$. Bowman E., Soga K. y Drummond T. (2001), "Particle shape characterization using Fourier descriptor analysis”. Géotechnique $51 \mathrm{~N} 0$. 6.

Clark M. (1981), "Quantitative shape analysis: a review". Mathematical Geology. Vol. 13 No.4, pp. $303-320$. De Larrard F. (1999), "Concrete Mixture Proportioning: a Scientific Approach", Editado por Taylor \& Francis, Primera Edición Galloway J. (1994), "Grading, Shape, and Surface Properties”. ASTM Special Technical Publi-cation N o. 169C, Philadelphia, pp. 401410.

Hudson B. (1998), "Aggregate Shape Affects Concrete Cost", Q uarry, N oviembre 1998, pp 1-4

IN VIAS (1998), "N orma técnica de referencia IN V E 230. Índice de alargamiento y aplanamien-to de los agregados para carreteras.", Instituto Nacional de Vías - Colombia

Kaplan M. F. (1959), "Flexural and Compressive Strength of Concrete as Affected by the Prop-erties of Coarse Aggregates". American Concrete Institute Journal , Vol. 55, pp. 1193-1208.

Kosmatka S. (1994), "Bleeding" ASTM Special Technical Publication No. 169C, Philadelphia, pp 89-111.. Legg F. (1998), "Aggregates: Chapter 2" Concrete Construction Handbook. Cuarta edición, Editado por McGraw-Hill: New York, NY, USA. 
Maerz N. y Zhou W. (1999), "Calibration of optical digital fragmentation measuring systems". FRAG BLAST 6 - The Sixth International Symposium for Rock Fragmentation by Blasting, Jo-hannesburg, South Africa.

Mehta K. y Monteiro P. (1993), “Concrete: Structure, Properties, and materials” 2da Edición Prentice-Hall, Englewood Cliffs, N.J. Q uiroga P. (2003), "The Effect of the Aggregates Characteristics on the Performance of Port-land Cement", Austin: U niversidad de Texas. Documento de defensa de tesis doctoral.

Sánchez D. (1996), (3ae ed.) "Tecnología del concreto y del mortero". Bogotá: Bhandar

Shilstone J. (1990), "Concrete Mixture Optimization". Concrete International, Vol. 12 Issue 6, pp 33-39.

Shilstone J. (1999), "The Aggregate: The Most Important Value-Adding Component in Con-crete". International Center for Aggregates Research; M emorias del Simposio Internacional Aus-tin, Texas

Sonka M., Hlavac V. y Boyle R. (1993), "Image Proceedings analysis and machine vision”. Editado por Chapman\&Hall, Londres, UK.

Wang L.B., Lai J.S. y Frost J.D. (1997), Fourier M orphological Descriptors of Aggregate Profiles. 2nd International Conference on Image Technology Applications in Civil Engineering, pp76-85, Sweden.

Wang, L. Wang, X., M ohammad,M . y Abadie, C. (2005), “U nified M ethod to Q uantify Aggregate Shape Angularity and Texture U sing Fourier Analysis" Journal of Materials in Civil Engineer-ing, Vol 17 Issue 5, pp 498 - 504 